\title{
OSOVNIŠKA JAMA, THE CAVE IN ISOLATED KARST IN THE EAST OF SLOVENIA
}

\author{
OSOVNIŠKA JAMA, JAMA OSAMELEGA KRASA \\ VZHODNE SLOVENIJE
}

\author{
NADJA ZUPAN HAJNA ${ }^{1}$
}

${ }^{1}$ Karst Research Institute ZRC SAZU, Titov trg 2, SI- 6230 POSTOJNA, SLOVENIA, e-mail: zupan@zrc-sazu.si

Prejeto / received: 12. 7. 2002 
Nadja Zupan Hajna: Osovniška jama, jama osamelega krasa vzhodne Slovenije

Osovniška jama je bila odkrita leta 2001 med izkoriščanjem srednjemiocenskega apnenca v kamnolomu Pijevci v vzhodnem delu Slovenije. Subpanonski osameli kras je značilen za ta del Slovenije. Ta kras je razvit na majhnih otokih plitvega apnenca. Subpanonski osameli kras je poseben tip krasa na litotamnijski apnencih, kjer so površinske oblike dobro razvite ni pa znanih daljših jam. Osovniška jama je dolga okrog $290 \mathrm{~m}$ in je sedaj najdaljša jama v temu delu Slovenije. Na tem področju vpadajo apnenčeve plasti generalno proti JV pod kotom $20^{\circ}$. Glavne tektonske strukture so v smereh SZ-JV in V-Z. V kamnolomu je grebenski apnenec masiven in razpokan v smereh V-Z, SZ-JV in S-J. Jama generalno sledi smeri SZ-JV. Oblika rovov še zmeraj kaže na oblikovanje v freatičnih pogojih; večinoma pa je izraženo preoblikovanje in oblikovanje rovov v vadozni coni. V nekem obdobju razvoja jame so alohtoni klastični sedimenti napolnjevali zgornje dele jame, kasneje pa so bili skoraj popolnoma izprani. V jami je veliko kapniških tvorb.

Ključne besede: osameli kras, jama, litotamnijski apnenec, kamnolom Pijevci, vzhodna Slovenija.

\section{Abstract}

UDC: $551.44(497.4-11)$

\section{Nadja Zupan Hajna: Osovniška jama, the cave in isolated karst in the east of Slovenia}

Osovniška jama has been discovered in 2001 during the exploitation of the Middle Miocene limestone in Pijevci quarry in the E part of Slovenia. Isolated subpanonian karst is typical of this part of Slovenia. This karst developed on small isolated patches of shallow limestone. Subpanonian isolated karst is a special type of karst on Lithothamnian limestone, where the surface karst forms are very well developed but no long caves were known. Osovniška jama is about $290 \mathrm{~m}$ long and now is the longest cave in this part of Slovenia. In this area the general dip of limestone beds is towards SE at dip angle $20^{\circ}$. The main tectonic structures of the area are in NW-SE and E-W directions. In the quarry, reef limestone is massive and fissured in E-W, NW-SE and N-S directions. The cave generally follows the NW-SE direction. The shape of channels still shows its formation in phreatic conditions; but mostly the transformation and formation of its channels in the vadose zone is expressed. At some time in this cave development allochtonous clastic sediments filled up the upper parts of the cave; afterwards they were almost entirely washed away. There are a lot of flowstone formations in this cave.

Key words: isolated karst, cave, Lithothamnian limestone, Pijevci Quarry, East Slovenia. 


\section{INTRODUCTION}

In the spring 2001 during the works in the Pijevci quarry near Lemberg, north of Šmarje (coordinates: $\mathrm{y}=5542150, \mathrm{x}=5122738, \mathrm{z}=320 \mathrm{~m}$ ) a cave was discovered. It was named after the nearby peak Osovniška jama. The owner of the quarry Viktor Strašek, Sotensko near Šmarje, asked the collaborators of the Karst Research Institute ZRC SAZU to survey the cave and to carry out karstological control. The cave is being explored by the cavers of the Caving Club Črni galeb of Prebold. The location of the cave is shown on Fig. 1

Thus the total length of the two parts was 219 $\mathrm{m}$ and reached depth 18 $\mathrm{m}$. The cave is interesting due to its length as this is now the longest one in this part of Slovenia; an additional

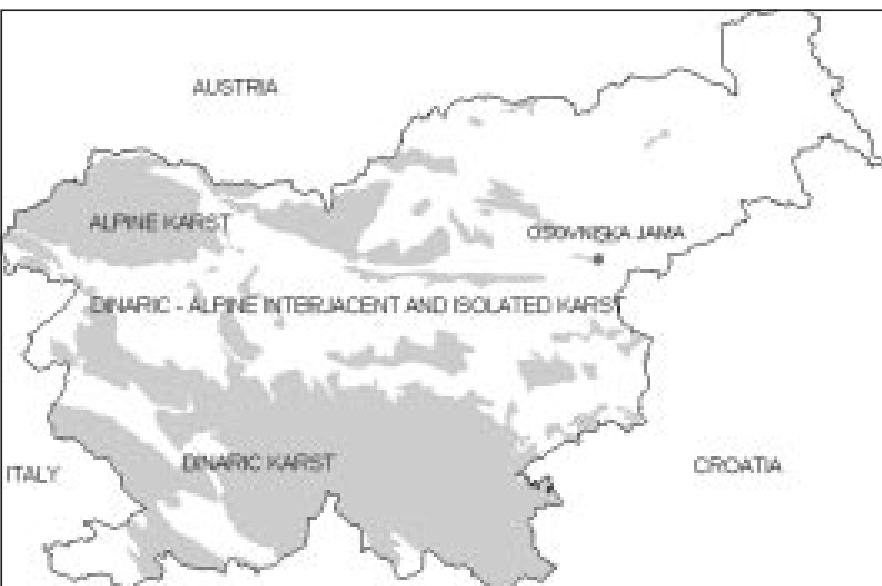

Fig. 1: Osovniška jama is developed in the isolated Pre-Panonnian karst in the east of Slovenia (Karst distribution after Habič 1982). Sl. 1: Osovniška jama je oblikovana v osamelem Subpanonskem krasu vzhodne Slovenije (Razporeditev krasa po Habič 1982). point of interest is the fact that it developed in relatively young limestones of the Middle Miocene comprised of reef organisms and remains of red algae. It is typical of these young limestones that they are much less solid than older ones. The surface is karstified and dotted with dolines, but so far no other cave has been discovered in this patch of isolated karst between Ponikve and Mestinje.

\section{ISOLATED KARST AS A TYPE OF KARST}

Slovenia, as a relatively small area boasts numerous types of karst with all superficial and underground features which are elsewhere in the world extended over several hundred kilometres (Gams 1974). Related to geological, hydrological, morphological and landscape conditions Habič (1969) divides karst in Slovenia into three larger units: Alpine karst, Dinaric karst and intermediary pre-Alpine and pre-Panonnian isolated karst which are subsequently, due to morphological and hydrographical properties, subdivided into smaller regions. Habič (1982) divides karst in Slovenia on the base of lithological types also distinguishing morphological, hydrographical and speleological properties.

Isolated karst is represented by single shallow islands of limestones and dolomites of various ages in the central part of Slovenia, strongly differing in structure and hydrology (Habič 1969); 
this is why different hydrogeological types of isolated karst exist in this part of Slovenia. PrePannonian isolated karst in the eastern part of Posavsko hribovje and Slovenske gorice is a special type of superficial and underground karst developed in the Miocene lithothamnian, marl and sandy limestones; in general they are less cavernous (Habič 1982). Due to the geological properties of lithothamnian limestone, in particular poor bedding and unfavourable crushing, only the surface was karstified as rainwater hardly percolated into the interior (Habič et al. 1978).

Osovniška jama developed in such a patch of lithothamnian limestone extending from Ponikve to Mestinje on the north from Šmarje near Jelše in E Slovenia (Fig. 2).

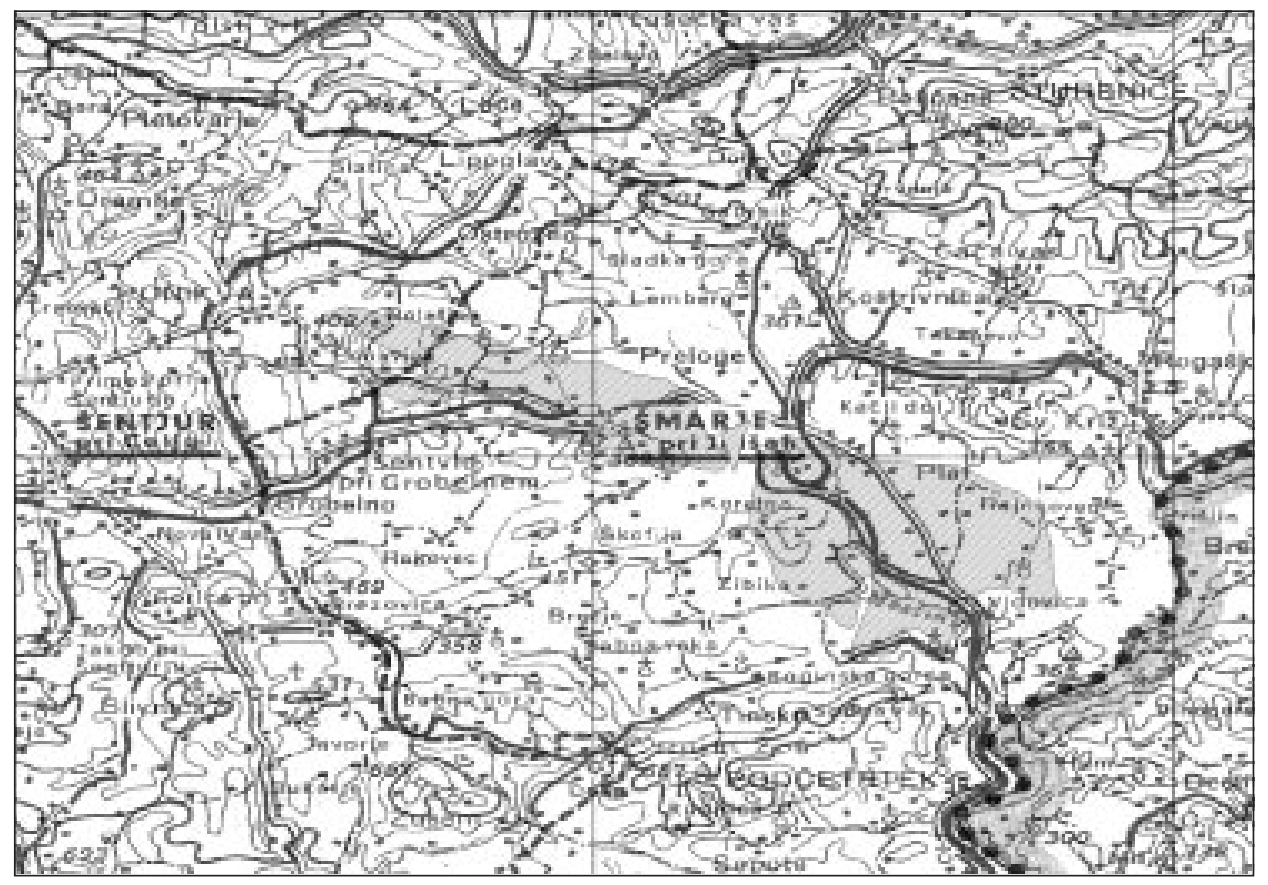

Fig. 2: Isolated karst on lithothamnian limestone between Ponikva and Mestinje with marked entrance to Osovniška jama (Base is map of Slovenia 1 : 250000).

Sl. 2: Osameli kras na litotamnijskem apnencu med Ponikvo in Mestinjami z označenim vhodom v Osovniško jamo (Osnova je karta Slovenije 1 : 250000).

\section{GEOLOGY OF THE AREA AND KARSTIFICATION}

In the direction $\mathrm{E}-\mathrm{W}$ between Ponikve and Mestinje there extends a belt of lithothamnian limestone of Medium Miocene age (Aničić \& Juriša 1984; Buser 1977). Lithothamnian limestone is a reef limestone deposited in a shallow Pannonian Sea into which rivers transported gravel, sand and clay giving origin to conglomerate, sandstone and marl. The limestone beds dip S - E. The main fault zones of the area trend NW - SE (Aničić \& Juriša 1985). After deposition of 


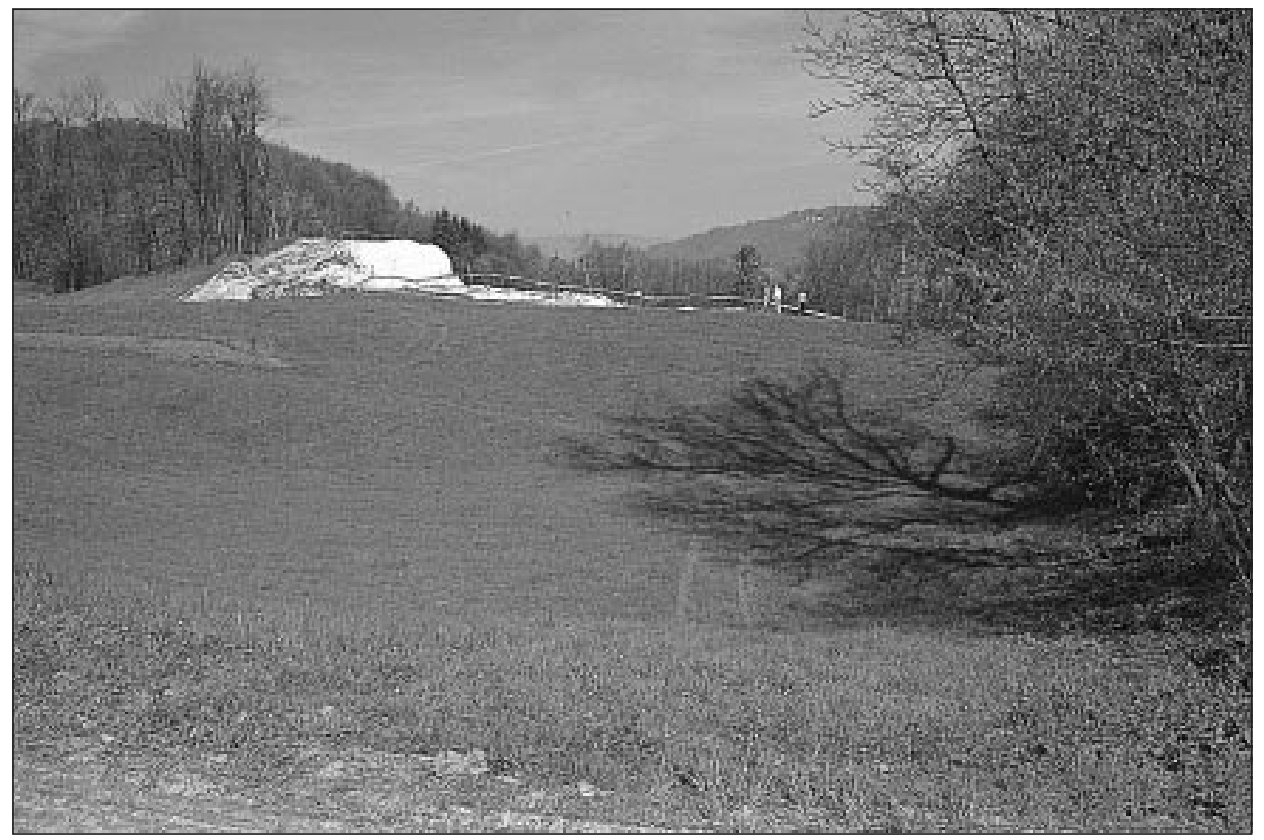

Fig. 3: Pijevci quarry with doline in front of the picture. Below the doline the upper part of the cave is ended.

Sl. 3: Kamnolom Pijevci z vrtačo v ospredju slike. Pod vrtačo se konča zgornji del jame.

lithothamnian limestone the neotectonic movement was very intensive as one can find lithothamnian limestone on Bohor at $780 \mathrm{~m}$ a.s.l., at levels between 400-500 m but also at the border of valleys at 200-300 m (Habič et al. 1978). The surface of the isolated karst lowers from west between Ponikve and Mestinje at $400 \mathrm{~m}$ eastwards to about $300 \mathrm{~m}$.

The Pijevci quarry is located below the highest peak, Osovnica, $369 \mathrm{~m}$ high. Here the lithothamnian belt narrows, the Mestinjščica flow cuts it and on the east of the flow the belt of the same type of limestone continues towards Rogaška Slatina. The surface around Pijevci is karstified, there are many dolines (Fig. 3) and some sinkholes and so far no known caves. Limestones are shallow, the lowest doline of the eastern slope verging towards the Mestinjščica on the east of Osovnica is at $290 \mathrm{~m}$ a.s.l. The springs between Dvor and Preloge near Šmarje are situated below $300 \mathrm{~m}$ a.s.l., for example the spring Šumeček, the nearest to the cave, is $295 \mathrm{~m}$ a.s.l. where lithothamnian limestone contacts underlying non-carbonate rocks. The thickness of limestone between the Osovnica peak and the Šumeček spring is only $75 \mathrm{~m}$, and the bottom of the cave lies about $7 \mathrm{~m}$ above the non-carbonate base.

Caves known so far in the same belt of lithothamnian limestone are located on the east of Ponikve; these are Brezno pri Debelaku, cad.no. 4195, $10 \mathrm{~m}$ deep and Hudičeva (Vragova) luknja, cad. no. 4196, in the Bukovica slope, $9 \mathrm{~m}$ deep.

The longest cave in lithothamnian limestones in general is Glija jama near Planina pri Sevnici, SW of Pijevci, about 200 m long (Habe 1972). 


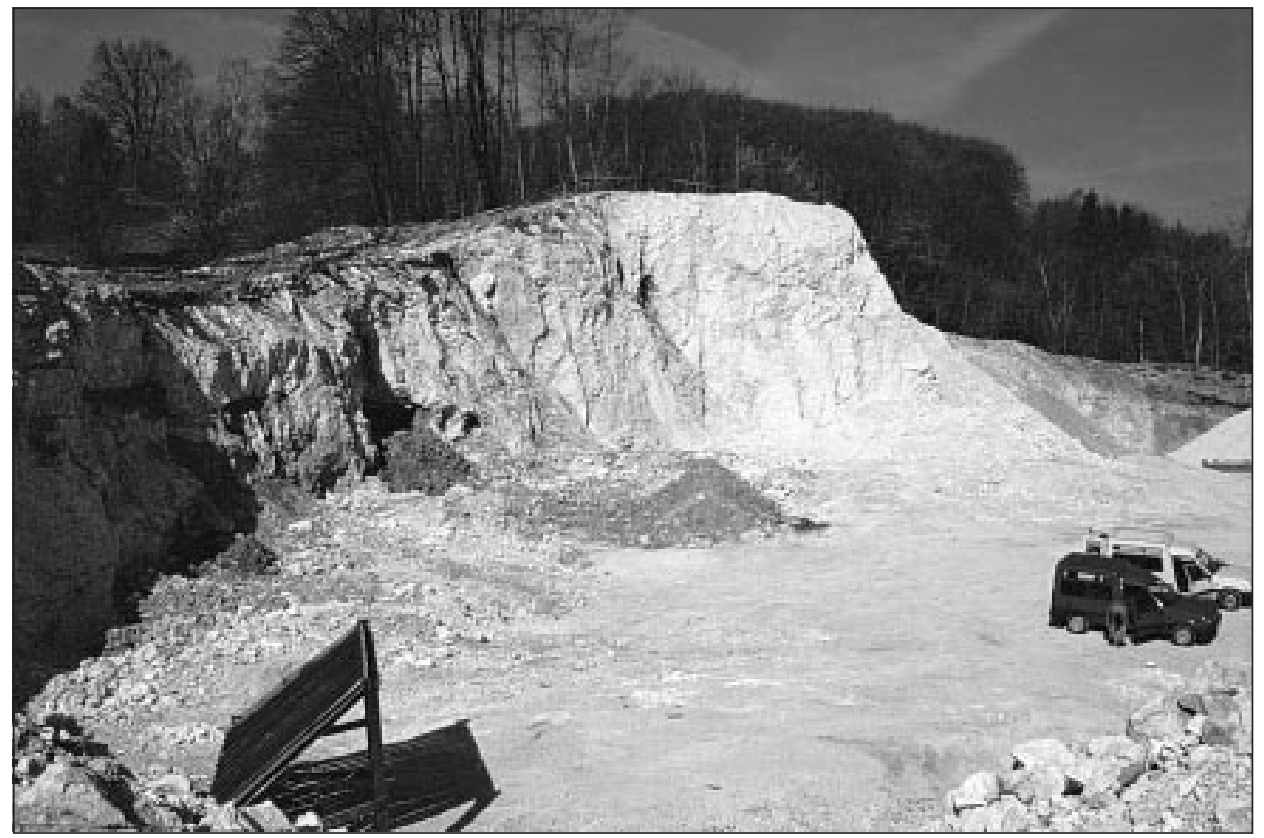

Fig. 4: Middle Miocene lithothamnian limestone in the quarry is massive and heavy tectonic crushed.

Sl. 4: Srednjemiocenski litotamnijski apnenec je v kamnolomu masiven in močno tektonsko pretrt.

There are several known caves near Boč, north-east from Pijevci but they developed in Permian and Triassic limestone. The caves in this area are: Balunjača, cad.no. 1067, 9 m long; Mala jama on Boč, cad.no. 1733, 11 m long; Požiralnik pri bolnišnici, cad.no. 3308, 17 m long; and Požiralnik pri Frmili, cad.no. 3309, 33 m long.

\section{THE LOCATION OF THE CAVE AND ITS MORPHOLOGICAL PROPERTIES}

The entrance into the cave opened in the Pijevci quarry where the lithothamnian limestone at $320 \mathrm{~m}$ a.s.l. is being exploited (Fig. 5). In the area of the quarry the limestone is very crushed and no beds are visible, reef limestone (Fig. 4).

The cave is divided into two parts and in April 2001 there was no accessible connection between them. In that time in the wall of the quarry 3 smaller passages, filled by layers of sand and loam sediments were visible. In general the cave lies from NW to SE direction, in 2001 two passages were accessible but there was no open connection between them (Fig. 5).

In spring 2001 Entrance 1 opened into a smaller passage, in total $40 \mathrm{~m}$ long. The main passage, $29 \mathrm{~m}$ long, branches into two smaller passages ending by breakdown. Breakdowns are due to quarrying works. The continuation of the passage towards the west is closed by flowstone. The ceiling of the passage is $7 \mathrm{~m}$ below the surface. 
The cross-section of the passage has a key-hole shape in the upper part is the relict of a former phreatic tube passage into which later a narrow meander incised gravitationally. In the walls of the passages corrosion notches are clearly visible at different levels developed by gradual adaptation of water flow to inflow and outflow. In this part of the cave wall notches dip NE (40/20), showing the same water flow direction towards the face of the quarry. The channel developed in the phreatic zone while the meander is probably of vadose origin. At a certain stage meander was completely filled up by clastic sediments of allochthonous origin. During the development the channel was emptied again.

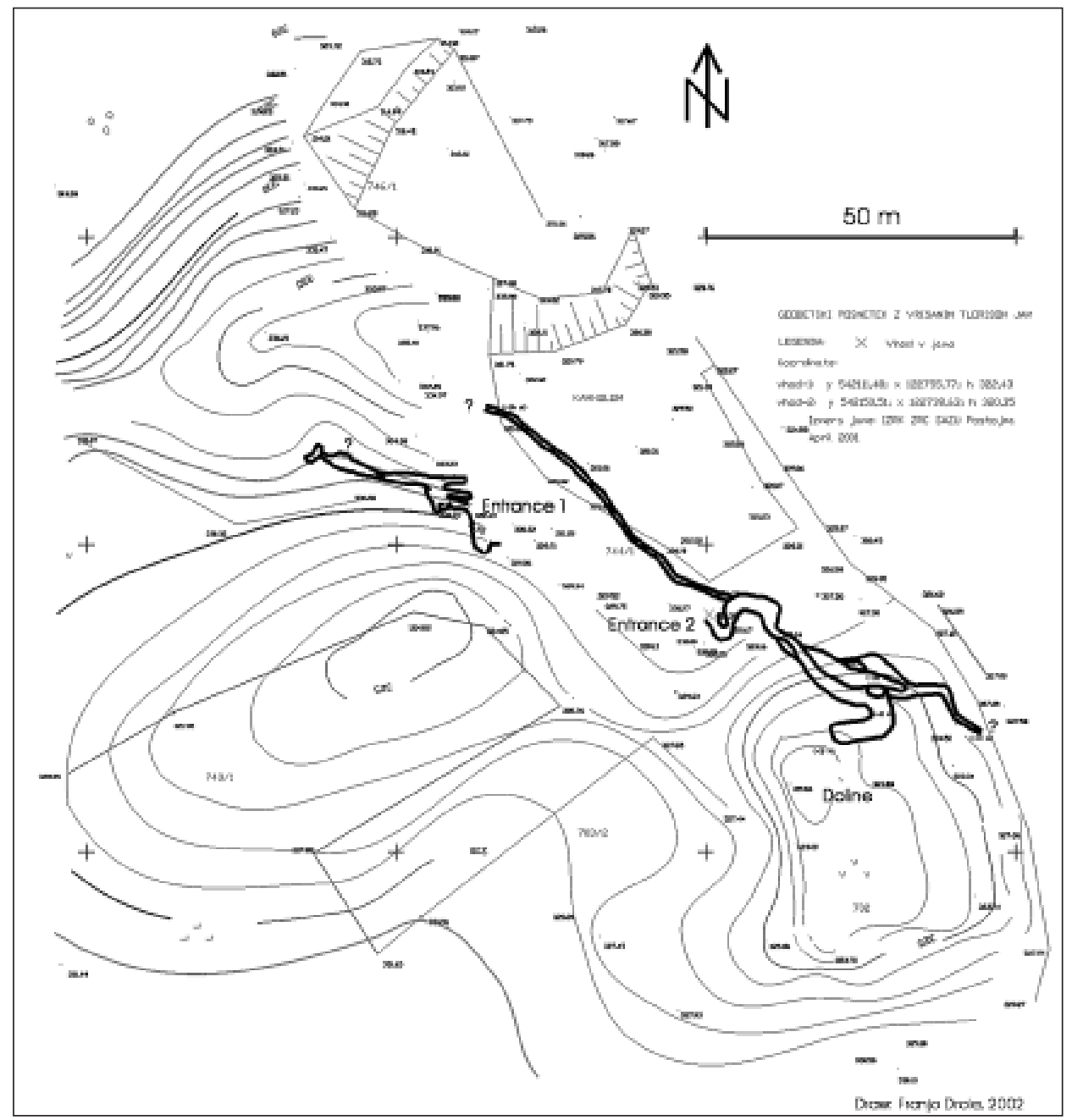

Fig. 5: Basic plan of Osovniška jama in Pijevcy quarry. Cave general follows NW - SE direction. Sl. 5: Tloris Osovniške jame v kamnolomu Pijevci. Jama generalno sledi smeri SZ - JV. 
The passage was extremely well decorated and still there is flowstone of various shapes. Specially good are onion-like speleothems on the ceiling near the entrance to the passage and needle-like formations on the wall of the meander. Now the passage is plundered, speleothems broken and the entrance into this part of the cave extremely crumbly. The danger of collapse is high in the passage, particular in its entrance part where it is crossed by a N-S strong fissure. The fissure is a new one opened due to quarry works and lies in the middle of an already existing tectonically crushed zone.

Entrance 2 leads into the main part of the cave with passages at three levels. In spring 2001 the entrance into the cave was located at a fault zone, trending 300-120, vertically rotated in a shape of letter S. The first level, $38 \mathrm{~m}$ long lies $13 \mathrm{~m}$ below the surface. The passage is up to 2,5 $\mathrm{m}$ high and up to $3 \mathrm{~m}$ wide. The shape is an inclined meander with a visible relic of a phreatic channel at its top. Speleothems of various shapes are preserved all over the passage. The upper part of the cave ends with a smaller chamber; on the south a well decorated, though short passage continues towards the surface (there is only $3 \mathrm{~m}$ to the bottom of the doline above on Fig. 3). Below the step one of the passages continues at the same level towards SE and ends after $19 \mathrm{~m}$; and the other lowers towards NW where the lowest part of the cave lies. This lowest passage is directed from NW to SE and is so far $87 \mathrm{~m}$ long. The passage is $1,5 \mathrm{~m}$ wide and $11 \mathrm{~m}$ high. The percolation water stays in the bottom and in some places the passage is well decorated by stalagmites and smaller stalagmite deposits.

In 2001 the upper part of the cave was below the level of the quarry floor (320 $\mathrm{m}$ a.s.l.), the middle part was up to $10 \mathrm{~m}$ and lower part up to $18 \mathrm{~m}$ below the then quarry level. The passage of the lower part is $11 \mathrm{~m}$ high thus it was only $7 \mathrm{~m}$ below the lowest level of the quarry. Schematic extended profile is on fig. 6 . The bottom of the cave was only $7 \mathrm{~m}$ above the Šumeček spring which is about $400 \mathrm{~m}$ distant from the cave entrance towards SE.

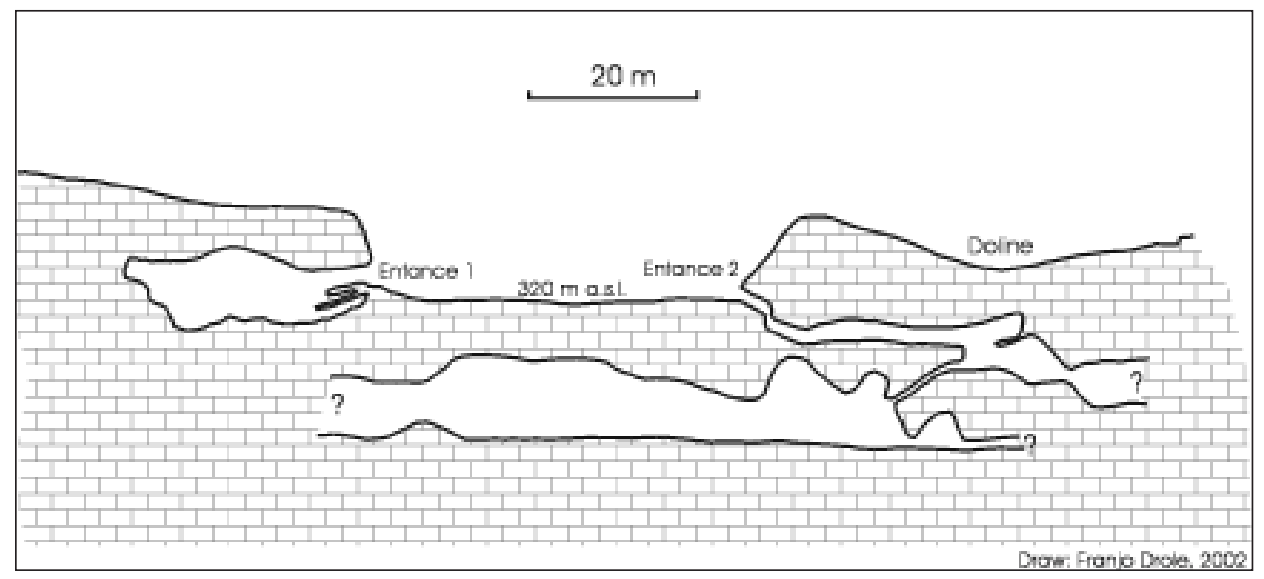

Fig. 6: Schematic extended profile of Osovniška jam in Pijevci quarry, in the year 2001. Sl. 6: Shematski iztegnjeni naris Osovniške jame v kamnolomu Pijevci leta 2001. 
Nadja Zupan Hajna: Osovniška jama, the cave in isolated karst in the east of Slovenia

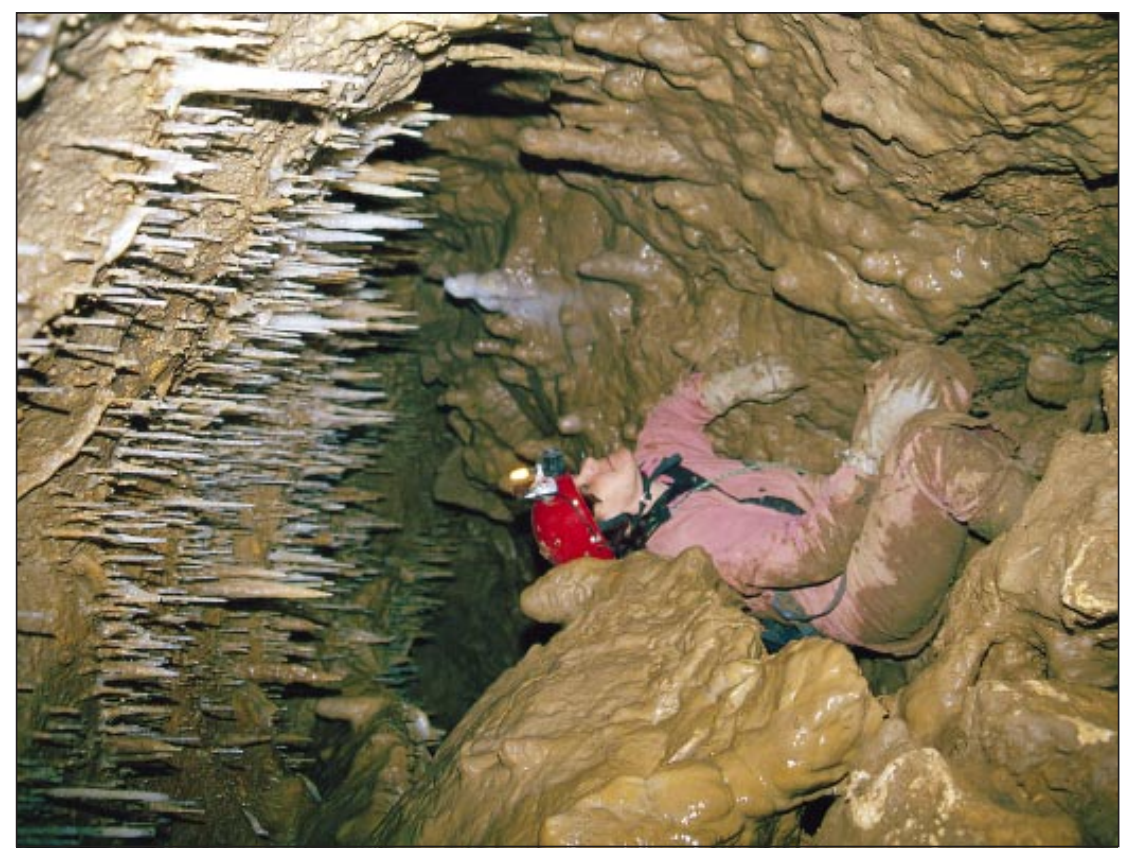

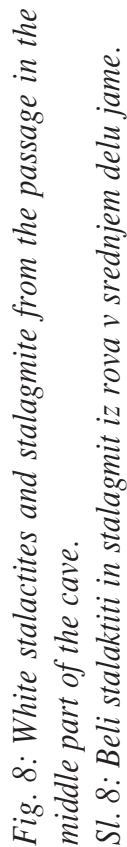

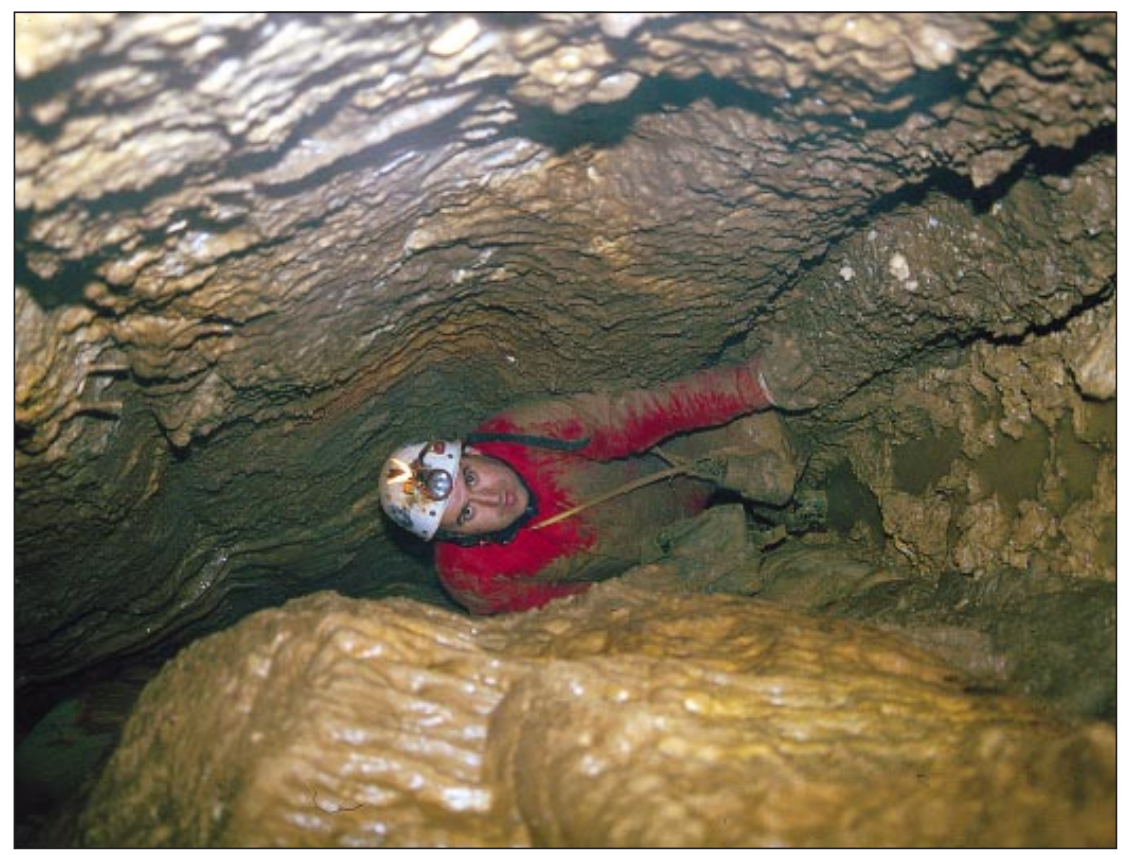

$\frac{2}{2}$

O

$\stackrel{2}{8}$

อุ

$\stackrel{2}{2}$

.

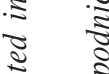

$\div \quad$

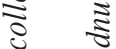

$\approx 2$

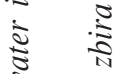

30

.

\%

¿ 0.

₹

$\therefore=2$

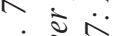

$\rightarrow \frac{1}{0}$ 


\section{CAVE ORIGIN AND CAVE SEDIMENTS}

The cave developed in lithothamnian limestone of the Middle Miocene age. When the Pannonian Sea started to retreat from this area the environment and then the physico-chemical controls changed to such a degree that limestone started to be karstified. According to the passage shape we think that the initial channels developed in the phreatic zone. When the gradient changed and the water outflow level dropped, water started to incise a meander in the bottom of the phreatic channel, gradually deepening and conforming it to new points of inflow and outflow from the area. In the upper part of the passage there is a former phreatic passage preserved and later, in the vadose zone it was gravitationally deepened. A narrow oxbow passage developed and this was later filled by sediments.

Once fluvial sediments entirely filled upper cave passages, lower were not formed in that time obviously, later they were washed away and now their remains may be seen on the passage walls and below flowstone layers.

Gravel rises mostly quartz pebbles of different colours (black, red, white, yellow-white) and of various sizes (up to several $\mathrm{cm}$ ). In several places quartz sand is mixed with gravel and in places this is a deposit on its own. Quartz gravel and sand are transported into the cave from the Miocene conglomerates and sandstones. According to the basic geological map the Lower Miocene layers of conglomerates and sands are in contact with lithothamnian limestone close to Pijevci in the north (Aničić \& Juriša 1984) on the northern slope of Sotensko below the quarry; there could be the origin of quartz gravel and sand. Yet the origin in Middle and Upper Miocene quartz conglomerates and quartz sand and sandstone lying on the south from Pijevci, the area of Dvorski and Preloški streams, could also be possible. Additional analyses are required to ascertain the origin of pebbles and sand.

Breakdowns in the cave show cave collapse near the surface mostly and at the crossing of different tectonic zones (in the chamber).

Water flows into the cave through open fissures and collects at the floor of the passages. Percolation water washes both clay particles from the fissures and older sediments, later depositing them as mud in lower parts of the cave. Among the sediments washed into the cave by fissures (below a doline) quartz pebbles and pieces of charcoal were found in the clay.

Chemical sediment in the cave is flowstone of various shape depending on the mode of water percolation. White colour prevails (Fig. 8) there are also transparent and brown flowstones showing the purity of limestone in which the cave developed. A lot of flowstone is recent, depositing from now percolating water. Flowstones were not yet dated.

\section{CONCLUSION}

The cave is very interesting, in particular due to its origin in young Middle Miocene lithothamnian limestones, the small number of caves in this part of Slovenia and in this type of karst in general, and also due to the shape of cave passages where remains of phreatic channels are preserved and due to well-preserved speleothems.

As the quarry continues to work by deepening its bottom the consequences because of blasting will have a negative impact on the main part of the cave and this is a pity. 


\section{REFERENCES}

Aničić, B. \& Juriša, M., 1984: Osnovna geološka karta 1 : 100000, list Rogatec. Zvezni geološki zavod, Beograd.

Aničić, B. \& Juriša, M., 1985: Tolmač lista Rogatec, Osnovna geološka karta 1 : 100000, Zvezni geološki zavod, 76 str., Beograd.

Buser, S., 1977: Osnovna geološka karta 1 : 100000, list Celje. Zvezni geološki zavod, Beograd. Gams, I., 1974: Kras. Slovenska matica. 359 p, Ljubljana.

Habe, F., 1972: Nekatere speleološke značilnosti osamljenega krasa Slovenije. Naše jame, 13 (1971), 45 - 53, Ljubljana.

Habič, P., 1969: Hidrografska rajonizacija krasa v Sloveniji. Krš Jugoslavije, 6, 79-91, Zagreb.

Habič, P., 1982: Pregledna speleološka karta Slovenije. Acta carsologica, 10 (1981), 5-22, Ljubljana.

Habič, P., Gospodarič, R., Habe, F., Kenda, I., Kranjc, A. \& Šušteršič, F., 1978: Speleologic Map of Slovenia, $4^{\text {th }}$ Cont. Naše jame, 19 (1977), 55-57, Ljubljana.

Inštitut za geodezijo in fotometrijo, 1982: Pregledna karta Slovenije 1 : 250000, Republiška geodetska uprava, Ljubljana.

\section{OSOVNIŠKA JAMA, JAMA OSAMELEGA KRASA VZHODNE SLOVENIJE}

\section{Povzetek}

Osovniško jamo so odkrili pomladi leta 2001 med deli v kamnolom Pijevci pri Lembergu severno od Šmarij (koordinate: $y=5542150, x=5122738, z=320 \mathrm{~m}$ ). Po bližnjem vrhu so jo poimenovali Osovniška jama. Lastnik kamnoloma je Viktor Strašek s Sotenskega pri Šmarju, na katerega željo smo sodelavci z Inštituta za raziskovanje krasa ZRC SAZU jamo izmerili in v njej opravili tudi krasoslovni ogled. Jamo raziskujejo tudi člani jamarskega kluba Črni galeb iz Prebolda. Skupna dolžina izmerjenih rovov je bila takrat $290 \mathrm{~m}$, dosežena globina pa $18 \mathrm{~m}$. Jama je zanimiva zaradi svoje dolžine, zanimiva je tudi iz razloga, ker je oblikovana v relativno mladih srednjemiocenskih apnencih, ki jih gradijo grebenski organizmi in ostanki rdečih alg. Za te mlade apnence je značilno, da so v primerjavi s starejšimi veliko manj trdni. Površje je zakraselo in polno vrtač, večjih jam pa v tej krpi osamelega krasa med Ponikvami in Mestinjami do odkritja te jame niso poznali.

V Sloveniji se na majhnem prostoru nahajajo najrazličnejši tipi krasa z vsemi svojimi površinskimi in podzemeljskimi oblikami, ki so drugje po svetu razmaknjeni tudi po več sto kilometrov (Gams 1974). Glede na geološke, hidrološke, morfološke in pokrajinske razmere je Habič (1969) razdelil kras v Sloveniji na tri večje enote: na alpski kras, dinarski kras in vmesni predalpski ter predpanonski osameli kras, ki jih po morfoloških in hidrografskih razmerah deli še na manjše predele. Habič (1982) kras v Sloveniji deli tudi glede na osnovne litološke tipe, ki pa se med seboj ločijo po morfoloških, hidrografskih in speleoloških značilnostih. Predpanonski osameli kras v vzhodnem delu Posavskega hribovja in v Slovenskih goricah je poseben tip površinskega in podzemeljskega krasa, ki je razvit na miocenskih litotamnijskih, lapornatih in peščenih apnencih, ki so na splošno tudi manj prevotljeni (Habič 1982). Zaradi geoloških lastnosti litotamnijskega 
apnenca, predvsem slabe plastovitosti in neugodne pretrtosti, naj bi bilo zakraselo predvsem površje, v notranjost pa naj bi padavine težje pronicale (Habič et al. 1978).

Med Ponikvami in Mestinjami se v smeri V - Z vleče pas litotamnijskega apnenca srednje miocenske starosti (Aničić \& Juriša 1984, Buser 1977). Litotamnijski apnenec je po nastanku grebenska tvorba, ki se je odlagala v plitvem Panonskem morju v katerega so reke v istem času nanašale prod, pesek in gline, iz katerih so nastajali enako stari konglomerat, peščenjak in lapor. Plasti apnenca vpadajo proti JV. Glavne prelomne cone na tem področju so v smeri SZ - JV (Aničić \& Juriša 1985). Neotektonsko gibanje je bilo po odložitvi litotamnijskih apnencev zelo intenzivno, saj so na primer litotamnijski apnenci na Bohorju v nadmorski višini $780 \mathrm{~m}$, gradijo nivoje na 400-500 m, najdemo jih pa tudi na obrobju dolin v nadmorski višini 200-300 m (Habič et al. 1978). Površje krpe osamelega krasa med Ponikvami in Mestinjami se od zahoda spušča proti vzhodu, s 400 m nadmorske višine na okrog 300 m. Kamnolom Pijevci se nahaja pod najvišjim vrhom Osovnico, ki je visoka 369 m. Pri Osovnici se pas litotamnijskega apnenca močno zoži, preseka ga potok Mestinjščica, vzhodno od potoka pa se pas istega apnenca nadaljuje proti Rogaški Slatini. Površje okrog Pijevcev je zakraselo, pojavljajo se številne vrtače in nekaj grezov, jam pa tu do sedaj ni bilo znanih. Apnenci so tu plitvi, najnižja vrtača je na vzhodnem pobočju, ki se spušča proti Mestinjščici, vzhodno od Osovnice, na nadmorski višini $290 \mathrm{~m}$. Izviri med Dvorom in Prelogami pri Šmarju so na višini pod 300 m, jami najbližji izvir Šumeček je na primer na nadmorski višini 295 m, kjer je tudi litotamnijski apnenec v stiku s spodaj ležečimi nekarbonatnimi kamninami. Debelina apnenca med vrhom Osovnice in izvirom Šumečka je samo okrog 75 m, dno jame pa je približno $7 \mathrm{~m}$ nad nekarbonatno podlago. Do sedaj znani jami v istem pasu litotamnijskega apnenca, se nahajata vzhodno od Ponikve, to sta: $10 \mathrm{~m}$ globoko Brezno pri Debelaku s katastrsko številko 4195, na hribu Kozjak; in 9 m dolga Hudičeva (Vragova) luknja s katastrsko številko 4196, na pobočju Bukovice. Najdaljša jama v litotamnijskih apnencih sploh, pa je Glija jama v Planini pri Sevnici, SW od Pijevcev, ki meri okrog 200 m (Habe 1972).

Vhod v jamo je na nadmorski višini $320 \mathrm{~m}$. Apnenec je na področju kamnoloma močno tektonsko pretrt, plasti pa niso vidne (grebenski apnenec). Jama je razdeljena $\mathrm{v}$ dva dela, med katerima aprila 2001 ni bilo odprte povezave. V steni kamnoloma so bili v tem času vidni še 3 manjši rovi zatrpani s plastmi peščenih in ilovnatih sedimentov. Generalno se razteza jama v smeri SZ - JV, leta 2001 sta bila dostopna dva rova, ki med seboj nista imela odprte povezave.

Vhod 1, se je pomladi leta 2001 odpiral v krajši rov, katerega skupna dolžina je bila $40 \mathrm{~m}$. Ta rov ima generalno smer V - Z, posamezni deli rova so razviti tudi v smeri SZ - JV in S - J. Prečni prerez rova ima obliko ključavnice, $\mathrm{v}$ vrhu rova je ostanek prvotnega freatičnega kanala -cevi, $\mathrm{v}$ katerega se je kasneje gravitacijsko poglobil ozek meander. V stenah rovov so lepo vidne stenske zajede v več različnih nivojih, ki so nastale ob postopnem prilagajanju vodnega toka točki vtoka in iztoka. Stenske zajede v tem delu jame vpadajo proti SV (40/20), kar kaže na isto smer vodnega toka, to je proti odkopnem čelu kamnoloma. Kanal se je izoblikoval v freatični coni, meander pa je po vsej verjetnosti vadoznega nastanka. Meander je bil s klastičnimi sedimenti alohtonega izvora v nekem obdobju popolnoma zapolnjen, ki so bili kasneje izprani. Rov je bil pred odkritjem izredno lepo zasigan, še vedno se najde siga najrazličnejših oblik.

Vhod 2, vodi v glavni del jame, katere rovi se nahajajo $v$ treh nivojih. Vhod $v$ jamo je bil pomladi leta 2001 ob prelomni coni s smerjo 300 - 120, ki vertikalno povija v obliki črke S. Prvi nivo z 38 m dolžine rova je do $13 \mathrm{~m}$ pod površjem. Oblika rova je poševen meander, v vrhu 
katerega je viden ostanek freatičnega kanala. Po vsem rovu so ohranjeni kapniki različnih oblik. Zgornji del jame se konča $\mathrm{z}$ manjšo dvorano, za katero se na južni strani nadaljuje v isti višini krajši lepo zasigan rov, ki nato obrne proti zahodu in se polagoma dviguje proti površju, do dna vrtače nad njim manjka $3 \mathrm{~m}$, ta rov se po $14 \mathrm{~m}$ konča. Pod vrtačo so v rovu naplavljeni prodniki pomešani s prstjo in koščki oglja s površja. V končni dvorani zgornjega dela jame se čez manjšo $3 \mathrm{~m}$ stopnjo spustimo v nižje dele jame. Pod stopnjo se eden od rovov nadaljuje v isti višini proti JV in se po 19 m konča. Meandrast rov je poln cevčic in sigovih zaves. Drugi, nizki rov, se izpod stopnje strmo spušča proti SZ, kjer se nadaljuje najnižji del jame. Ta najnižji rov je tudi najdaljši, njegova dolžina je $87 \mathrm{~m}$ in poteka v smeri SZ in JV. Rov je širok do $1,5 \mathrm{~m}$ in visok do $11 \mathrm{~m}$. Prečni prerez rova ima obliko ključavnice, to je meander, ki se pod stropom razširi v freatični kanal. V dnu rova se zadržuje prenikajoča voda, ki skupaj s sedimentom tvori blatno kopel. Rov je na dnu mestoma tudi zasigan. Zgornji del jame je bil leta 2001 do $5 \mathrm{~m}$ pod nivojem kamnoloma (nadmorska višina $320 \mathrm{~m}$ ), srednji del jame do $10 \mathrm{~m}$ in spodnji del jame do $18 \mathrm{~m}$ pod takratnim nivojem kamnoloma. Rov spodnjega dela jame je visok $11 \mathrm{~m}$, tako da je bil takrat samo $7 \mathrm{~m}$ pod najnižjim nivojem kamnoloma. Dno jame je samo $7 \mathrm{~m}$ nad izviri Šumečka, ki je od vhoda v jamo oddaljen okrog $400 \mathrm{~m}$ proti JV.

Fluvialni sedimenti so nekoč popolnoma zapolnjevali zgornje jamske rove, sedaj njihove ostanke najdemo po teh stenah rovov in pod plastmi sige. V času zapolnitve zgornjih delov jame, spodnji očitno še niso obstajali v taki obliki kot jih poznamo danes. Prod sestavljajo v glavnem kremenovi prodniki različnih barv (črna, rdeča, bela, rumenobela) in različnih velikosti (do več $\mathrm{cm})$. Med prod je na več mestih primešan tudi kremenčev pesek. Kremenov prod in pesek sta v jamo nanesena iz miocenskih konglomeratov in peščenjakov. Po osnovni geološki karti so spodnjemiocenske plasti konglomeratov in peskov v kontaktu z litotamnijskim apnencem že takoj severno od Pijevcev (Aničić \& Juriša 1984), v severnem pobočju Sotenskega pod kamnolomom. Tako imajo kremenovi prodniki in pesek lahko izvor že v njih. Možen bi bil pa tudi izvor v srednje in zgornjemiocenskih kremenovih konglomeratih in kremenovem pesku in peščenjaku, ki se nahajajo južno od Pijevcev, področje Dvorskega in Preloškega potoka. Vendar bi bile za natančnejši izvor prodnikov in peska potrebne še dodatne analize.

Jama je izredno zanimiva, predvsem zaradi nastanka v mladih srednjemiocenskih litotamnijskih apnencih, zaradi majhnega števila jam v tem delu Slovenije in tem tipu krasa sploh, zaradi oblike jamskega rova, to je ostankov prvotnih jamskih kanalov, ki so nastali še v freatični coni, in ohranjenosti ter oblik kapniških tvorb. Ob nadaljevanju izrabljanja kamnoloma in poglobitvi njegovega dna, se bodo verjetno pokazale posledice miniranja tudi v glavnem delu jame, kar pa bi bilo škoda. 